\title{
Improvement of nitrate and nitrite reduction rates prediction
}

\author{
Carolina Estuardo \\ Departamento de Ingeniería Química \\ Facultad de Ingeniería \\ Universidad de Concepción \\ Barrio Universitario, Concepción, Chile \\ Tel: 56412204197 \\ Fax: 56412243750 \\ E-mail: chuilinir@udec.cl \\ M. Cristina Martí \\ Departamento de Farmacología \\ Facultad de Ciencias Biológicas \\ Universidad de Concepción, Concepción, Chile. \\ Tel: 56412203895 \\ Fax: 56412245925 \\ E-mail cmarti@udec.cl \\ César Huiliñir \\ Departamento de Ingeniería Química \\ Facultad de Ingeniería \\ Universidad de Concepción \\ Barrio Universitario, Concepción, Chile \\ Tel: 56412204197 \\ Fax: 56412243750 \\ E-mail: chuilinir@udec.cl

\section{Estrella Aspé Lillo} \\ Departamento de Ingeniería Química \\ Facultad de Ingeniería \\ Universidad de Concepción \\ Casilla 160-C Correo-3 \\ Concepción, Chile \\ Tel: 56412204534 \\ Fax: 56412243750 \\ E-mail: easpe@udec.cl

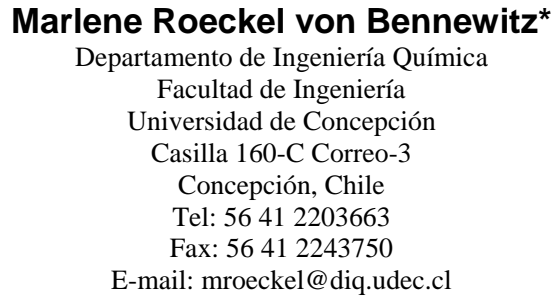

Financial support: Funded by grant FONDECYT No 1040495 (Chile).

Keywords: denitrification kinetics, nitrate reduction, nitrite reduction, $\mathrm{pH}$.

Abbreviations: TAN: total ammonia nitrogen

TOC: total organic carbon

VSS: volatile suspended solids

Reported models of denitrification rates integrate in an unique parameter the $\mathrm{pH}$-dependent inhibition by $\mathrm{HNO}_{2}$ and the $\mathrm{pH}$ effect on the bacterial metabolic activity; furthermore, they do not quantify separately the $\mathrm{pH}$ effect on the nitrate and on the nitrite reduction rates. The goal of this work was to quantify both effects on the kinetics of nitrate and nitrite reduction to improve the models' predictive value. Assays were performed at a $\mathrm{pH}$ range of $6.5-9.0$ in batch reactors at $37^{\circ} \mathrm{C}$ with an activated sludge. At the studied $\mathrm{pH}$ range

*Corresponding author 
and at below the $\mathrm{HNO}_{2}$ inhibitory concentration $\mathbf{( 0 . 0 0 4}$ $\mathrm{mg} \mathrm{L}^{-1}$ ), the maximum nitrate reduction rate diminished $23 \%$ and $50 \%$ by decreasing or increasing, respectively, one $\mathrm{pH}$ unit from 8.0. The maximum nitrite reduction at pH 8.0 diminished $15 \%$ at $\mathrm{pH} 7.0$ and $40 \%$ at pH 9.0. At $\mathrm{HNO}_{2}$ concentrations over the inhibitory concentration, except at $\mathbf{p H}>8.0$, the maximum nitrate reduction rate diminished $50 \%$ upon decreasing the $\mathrm{pH}$ from 8.0 to 7.0 or increasing it from 8.0 to 9.0. Inclusion of the $\mathbf{p H}$ effect in the reported models improved their predictive value; average deviations from the experimental data were reduced from $53 \%$ to $10.7 \%$ or $33.8 \%$ to $10.5 \%$ for nitrite and nitrate reduction rates, respectively.

Several food processing industries discharge their liquid effluents with high organic load to the environment causing ecological and public health problems.

Salmon-plant effluents have high protein (4.08- $22.5 \mathrm{~g}$ $\mathrm{COD} \mathrm{L}^{-1}$ ) and salinity loads (River et al. 1998). The salinity

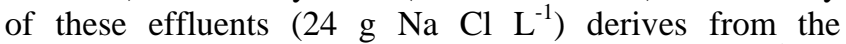
utilization of seawater (approximately $30 \mathrm{~g} \mathrm{Na} \mathrm{Cl} \mathrm{L}^{-1}$ ) in some of their processing. Due to their high carbon load, any biological treatment of these effluents should start by an anaerobic degradation. The anaerobic treatment of protein gives rise to ammonia; thus, although the original nitrate content in these effluents is almost negligible, further steps are required to aerobically oxidize the ammonia to nitrate (nitrification) and anoxically reduce nitrate to gaseous nitrogen (denitrification).

Several authors have suggested that $\mathrm{HNO}_{2}$ accumulation inhibit denitrification (Glass and Silverstein, 1998; Soto et al. 2007).

Nitrite is an intermediate in the denitrification process and depending on the $\mathrm{pH}$ and temperature of the medium could prevail as the ionized or the non-ionized form.

The $\mathrm{pH}$ can affect directly the bacterial growth and its enzymatic activities (Campos and Flotats, 2003), including denitrifying enzymes, and indirectly affect the denitrification rate through changes in the concentration of $\mathrm{HNO}_{2}$. If the non-ionized form of nitrous acid prevails, it can mask the direct inhibitory effect of the $\mathrm{pH}$.

Almeida et al. (1995) and Wild et al. (1995) have developed kinetic models to predict denitrification rates. However, these models have considered the apparent net $\mathrm{pH}$ effect, i.e., the $\mathrm{pH}$-dependent inhibitory effect of $\mathrm{HNO}_{2}$ and the $\mathrm{pH}$ effect on the bacteria activity in their kinetic expression. Moreover, Almeida et al. (1995) worked with a pure culture of $P$. fluorescens at $28^{\circ} \mathrm{C}$ while Wild et al. (1995) reported kinetic parameters at $20^{\circ} \mathrm{C}$.

Anoxic activated sludges usually include Pseudomonas fluorescens, Pseudomonas denitrificans, Paracoccus denitrificans and Micrococcus denitrificans, between other bacteria. A mixed bacterial population, as the ones used for effluents treatment, could exhibit different sensibilities to $\mathrm{pH}$ changes in the medium and to inhibitors than the ones reported in pure cultures.

The rate of nitrate reduction has been represented as a function of the nitrate concentration by the Monod equation (Almeida et al. 1995) and the rate of nitrite reduction has been represented by a Haldane-type kinetics, since high $\mathrm{HNO}_{2}$ concentrations inhibits this rate (Almeida et al. 1995; Glass and Silverstein, 1998).

Although it has been reported that the denitrification rate varies with a change in the $\mathrm{pH}$ (Almeida et al. 1995; Glass and Silverstein, 1998), the quantification of the direct $\mathrm{pH}$ effect on this rate or its inclusion in the kinetics of denitrification have not been reported in the literature.

There are different expressions for the pH-inhibition function for biological processes reported in the literature. Ramsay and Pullammanapallil (2005) modelled the effect of the $\mathrm{pH}$, up to $\mathrm{pH} 7.0$, on the acidogenic bacteria by an empiric relationship of the exponential type. Siegrist et al. (2002) included a non-competitive quadratic inhibition factor due to $\mathrm{pH}$ inhibition up to $\mathrm{pH}$ 7.0. Since the former relationships are empiric ones and for $\mathrm{pH}$ values below 7.0, the Michaelis function (Segel, 1975), initially proposed to quantify the dependence of the enzymatic activity on the $\mathrm{pH}$, seems the more appropriate expression to model the effect of the $\mathrm{pH}$ on the denitrification rate. This function
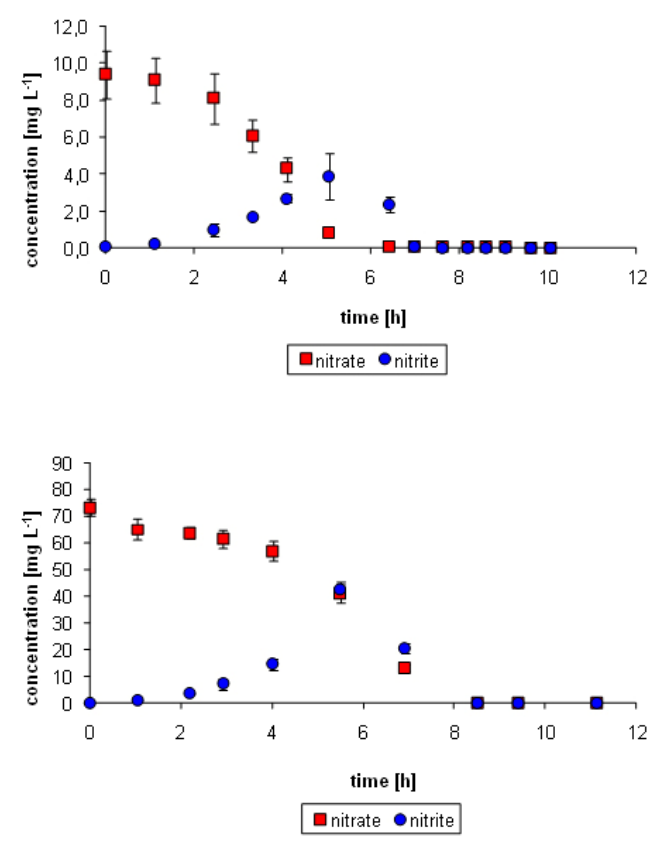

Figure 1. (a). Nitrate and nitrite concentration during denitrification at an initial nitrate concentration of $10 \mathrm{mg} \mathrm{NO}_{3}^{-}$ $-\mathrm{N} \mathrm{L}^{-1}, \mathrm{pH} 8$, biomass concentration $2.2 \mathrm{~g} \mathrm{~L}^{-1}$ and $37^{\circ} \mathrm{C}$. (b). Nitrate and nitrite concentration during denitrification at an initial nitrate concentration of $80 \mathrm{mg} \mathrm{NO}_{3}^{-}-\mathrm{N} \mathrm{L}^{-1}, \mathrm{pH} 8$, biomass concentration $11 \mathrm{~g} \mathrm{~L}^{-1}$ and $37^{\circ} \mathrm{C}$. 
pH effect on denitrification rates

Table 1. The possible maximum concentration of non-ionized nitrite as a function of the $\mathrm{pH}$ and initial nitrate concentration, assuming that nitrate is completely converted to nitrite and the latter accumulates.

\begin{tabular}{|c|c|c|}
\hline \multirow{2}{*}{$\mathbf{p H}$} & \multicolumn{2}{|c|}{$\begin{array}{r}\text { Maximal } \mathrm{HNO}_{2} \text { concentration }\left[\mathrm{mg} \mathrm{N}-\mathrm{HNO}_{2} \mathbf{~ L}^{-1}\right] \text { at an } \\
\text { initial nitrate concentration of: }\end{array}$} \\
\cline { 2 - 3 } & $\mathbf{8 0}\left[\mathrm{mg} \mathrm{NO}_{3}^{-}-\mathrm{N} \mathrm{L}^{-1}\right]$ & $\mathbf{1 0}\left[\mathrm{mg} \mathrm{NO}_{3}^{-}-\mathrm{N} \mathrm{L}^{-1}\right]$ \\
\hline 6.5 & 0.0420 & 0.0040 \\
\hline 7.0 & 0.0133 & 0.0017 \\
\hline 7.5 & 0.0042 & 0.0005 \\
\hline 8.0 & 0.0013 & 0.0002 \\
\hline 8.5 & 0.0004 & 0.0001 \\
\hline 9.0 & 0.00013 & 0.00002 \\
\hline
\end{tabular}

Source: GenHunter Corporation, TN.

has been modified to quantify the inhibitory effect of a wide range of $\mathrm{pH}$ values on the acetogenic step of the anaerobic process (Angelidaki et al. 1993; Batstone et al. 2002).

The goal of this work was to include the effect of the $\mathrm{pH}$ on the kinetics of nitrate reduction and nitrite reduction in the modelling of these rates, and evaluate its predictive value using experimental data obtained with a mixed denitrifying sludge for treatment at $37^{\circ} \mathrm{C}$ of a salmon plant effluent. Validation of the inclusion of the $\mathrm{pH}$ effect in the kinetics of denitrification will be assessed by calculating the fitting deviations of the reported models with and without the inclusion of $\mathrm{pH}$ function. An improvement of the predictive values of these models will broaden the use of the kinetics to different operational conditions.

\section{MATERIALS AND METHODS}

\section{Inoculum and culture medium}

An adapted, stable biomass, able to carry out denitrification and methanogenesis was obtained from $3 \mathrm{~L}$ anaerobic and anoxic reactors that were at steady state for at least a year. These reactors were fed with $50 \%$ of a salmon-plant effluent and $50 \%$ of a synthetic substrate $(\mathrm{v} / \mathrm{v})$; the latter to adapt the sludge to nitrate. The average industrial effluent composition was $\left(\mathrm{g} \mathrm{L}^{-1}\right)$ : $\mathrm{NO}_{3}^{-}, 0 ; \mathrm{NO}_{2}^{-} ; 0 ; \mathrm{NH}_{4}^{+}, 0.023$; total Kjeldahl nitrogen, 10.755; TOC, 2.482; COD, 6.469; NaCL, 24; protein, 2.536; $\mathrm{SO}_{4}{ }^{2}, 0.001$. The synthetic substrate composition was $\left(\mathrm{g} \mathrm{L}^{-1}\right): \mathrm{KH}_{2} \mathrm{PO}_{4}, 3 ; \mathrm{K}_{2} \mathrm{HPO}_{4}, 3$; $\mathrm{NaHCO}_{3}, \quad 0.4 ; \mathrm{MgSO}_{4} \cdot 7 \mathrm{H}_{2} \mathrm{O}, 0.005 ; \mathrm{NaCl}, 24$; yeast extract, 0.05; peptone casein, 0.12; $\mathrm{KNO}_{3}, 0.721$;
$\mathrm{FeSO}_{4} \cdot 7 \mathrm{H}_{2} \mathrm{O}, 0.0011 ; \mathrm{CaCl}_{2}, 0.0005 ; 17.5 \mathrm{M}$ acetic acid, $1.22 \mathrm{~mL}^{4}$.

\section{Bioreactors}

Kinetic assays at constant $\mathrm{pH}$ were carried out in 1-L batch reactors with a useful volume of $800 \mathrm{~mL}$ of anoxic medium. They were seeded with $20 \%(\mathrm{v} / \mathrm{v})$ of the adapted inoculum (50\% anaerobic and 50\% anoxic); the purpose of seeding the reactors with a large microbial concentration was to ensure a constant biomass throughout the assays. The reactors were fed with a mixture $(\mathrm{v} / \mathrm{v})$ of $50 \%$ salmon plant effluent and $50 \%$ of a synthetic substrate of the following composition $\left(\mathrm{g} \mathrm{L}^{-1}\right)$ : $\mathrm{NaHCO}_{3}, 0.4 ; \mathrm{MgSO}_{4}$ $7 \mathrm{H}_{2} \mathrm{O}, 0.005$; $\mathrm{NaCl}, 24$; yeast extract, 0.05 ; peptone casein, $0.12 ; \mathrm{FeSO}_{4} \cdot 7 \mathrm{H}_{2} \mathrm{O}, 0.0011 ; \mathrm{CaCl}_{2}, 0.0005 ; \mathrm{KCl}, 0.0005$ $\mathrm{CoCl}_{2}, 0.0005 ; 17.5 \mathrm{M}$ acetic acid, $1.22 \mathrm{~mL}$. In assays performed with initial nitrate concentrations of 10 or $80 \mathrm{mg}$ $\mathrm{NO}_{3}{ }^{-}-\mathrm{N} \mathrm{L}^{-1}$, nitrate was added to the medium as $\mathrm{KNO}_{3}$. A $\mathrm{C} / \mathrm{N}$ of 10 was used to avoid dissimilatory degradation of nitrate and nitrite to ammonia.

Anoxic conditions in the reactors were obtained by gassing for approximately 1 min with $\mathrm{N}_{2}$ and sealing the reactors with butyl stoppers. Temperature was kept constant at $37 \pm$ $1^{\circ} \mathrm{C}$ by means of a thermostatic bath; this assay temperature was chosen as it is the optimum temperature for anaerobic digestion. The $\mathrm{pH}$ was controlled ( \pm 0.1 units) by a Cole Palmer (ORP 5595, USA) controller; the $\mathrm{pH}$ was adjusted by the addition of $1 \mathrm{~N} \mathrm{HCl}$ or $1 \mathrm{~N} \mathrm{NaOH}$.

Samples were withdrawn every $40 \mathrm{~min}$ for 12 hrs and every 2 hrs for 16 hrs in kinetic assays performed at an initial 


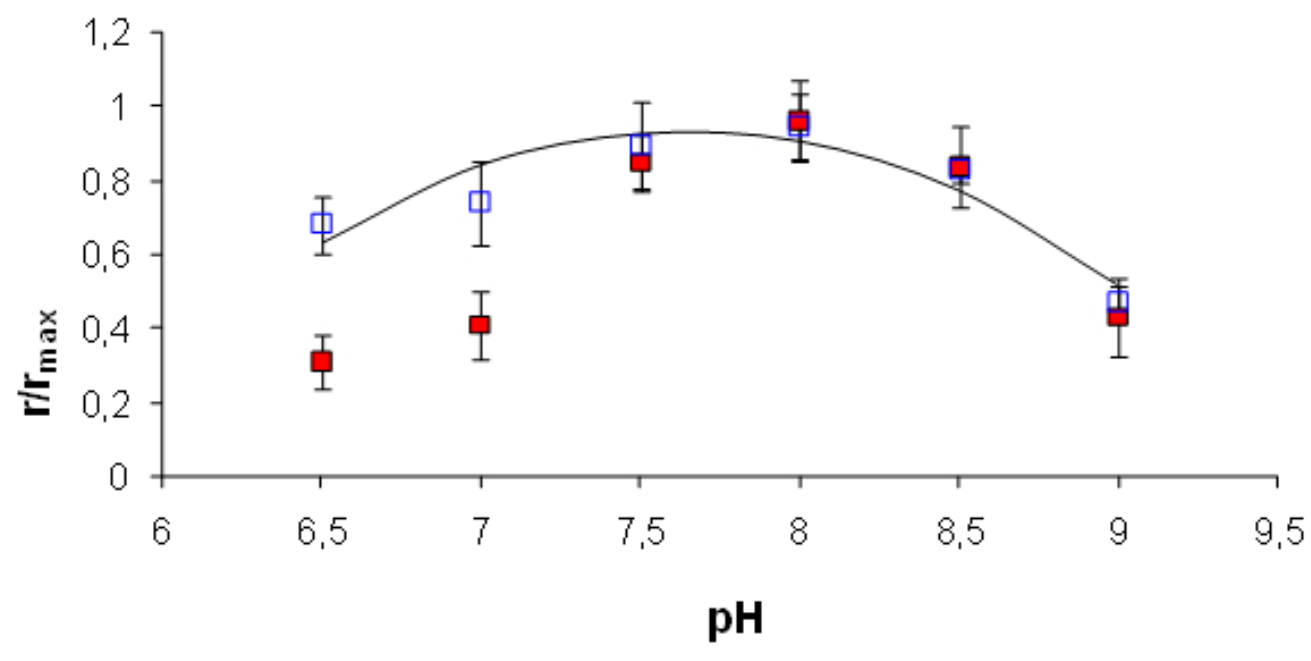

$80 \mathrm{mg} \quad \square \quad 10 \mathrm{mg} \longrightarrow$ Fitting of the experimental data by the Michaelis function

Figure 2. Effect of the $\mathrm{pH}$ on the $r / r_{\max }$ ratio (apparent maximum specific rate/maximum specific rate at the optimum $\mathrm{pH}$ ) of nitrate reduction $\left(\mathrm{C} / \mathrm{N}=10,37^{\circ} \mathrm{C}\right)$ at an initial nitrate concentration of $80 \mathrm{mg} \mathrm{NO}{ }_{3}^{-}-\mathrm{N} \mathrm{L}^{-1} ; 10 \mathrm{mg} \mathrm{NO}_{3}{ }^{-}-\mathrm{N} \mathrm{L}^{-1} ;(3 / 4)$. Fitting of the experimental data by the Michaelis function for $10 \mathrm{mg} \mathrm{NO}_{3}^{-}-\mathrm{N} \mathrm{L}^{-1}\left(\mathrm{R}^{2}=0.94\right)$.

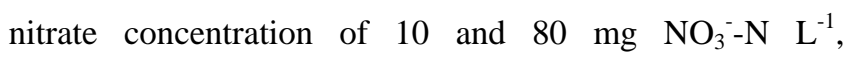
respectively. Liquid samples were centrifuged at $3500 \mathrm{rpm}$ for 4 min and filtered under vacuum with a $0.45 \mu \mathrm{m}$ filter membrane for bacteria removal.

\section{Chemical analyses}

In each sample, nitrite, nitrate, total ammonia nitrogen (TAN), volatile suspended solids (VSS) and total organic carbon (TOC) were measured as described elsewhere (Aspé et al. 2001; Sánchez et al. 2005). VSS were measured at the beginning and at the end of each assay. Total ammonia nitrogen was measured according to Standard Methods (APHA, 1992). Analyses were performed in triplicate.

\section{Theoretical background}

Maximal rates of nitrate and nitrite reduction.

The kinetic analysis used a simplified denitrification model:

$$
\mathrm{NO}_{3}^{-} \stackrel{r_{1}}{\longrightarrow} \mathrm{NO}_{2}^{-} \stackrel{r_{2}}{\longrightarrow} N_{2}
$$

Although other reduced products of denitrification have been reported, $\mathrm{pH}$ was thought to affect specially the nitrate and nitrite reduction rates.

The nitrate consumption rate can be described by:

$$
r_{1}=-k_{1} f\left(\mathrm{C}_{\mathrm{NO}_{3}^{-}}\right)
$$

Where $r_{1}$ is the rate of disappearance of nitrate, $k_{1}$ is a rate constant and $f\left(\mathrm{C}_{\mathrm{NO}_{3}^{-}}\right)$is any nitrate concentration function to be used in the kinetics of nitrate reduction.

The rate of nitrite consumption is:

$$
r_{2}=-k_{2} f\left(C_{\mathrm{NO}_{2}^{-}}\right)
$$

Where $f\left(\mathrm{C}_{\mathrm{NO}_{2}^{-}}\right)$is any nitrite concentration function to be used in the kinetics of nitrite reduction.

Nitrite is simultaneously formed and consumed, thus:

$$
r_{\text {Net nitrite }}=-r_{1}+r_{2}
$$

The initial maximal rates of nitrate consumption $\left(r_{1}\right)$ were obtained from the slope of a nitrate concentration vs time plot at different pHs. The net rate between nitrite accumulation and nitrite consumption, i.e. $r_{\text {net nitrite, was }}$ obtained from a nitrite concentration vs. time plot at different $\mathrm{pHs}$ and measuring the slope after nitrite has reached its maximal accumulation.

\section{Modelling of the pH effect}

Since the sludge used to denitrify in the present work is an anaerobic sludge, it is feasible to quantify the inhibitory effect of the $\mathrm{pH}$ on the denitrifying bacteria through mathematical functions representing the effect of the $\mathrm{pH}$ on anaerobic (acidogenic) bacteria. Several studies have 
included the inhibitory effect of the $\mathrm{pH}$ on the acidogenic bacteria as a factor that multiplies the substrate consumption rate:

$$
r_{i}=f\left(C_{i}\right) \cdot f(p H)
$$

Where

$r_{i}$ : Degradation rate of the compound $i$.

$f\left(C_{i}\right)$ : A mathematical expression that describes the kinetics of the substrate $i$ degradation as a function of the substrate concentration used.

$f(p H)$ : A mathematical expression that quantifies the $\mathrm{pH}$ effect.

The Michaelis function used to model the effect of the $\mathrm{pH}$ on enzymatic reactions was used to model the effect of the $\mathrm{pH}$ on nitrate and nitrite consumption rate (Segel, 1975):

$$
r=\frac{r_{\max }^{r}}{1+\frac{\left[H^{+}\right]}{K_{S 1}}+\frac{K_{S 2}}{\left[H^{+}\right]}}
$$

Or:

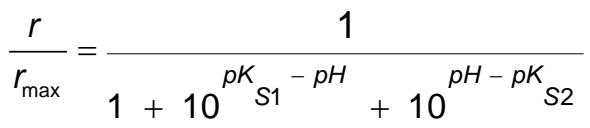

where: $r$, is the maximum apparent rate; $r_{\max }$, is the maximum rate at the optimum $\mathrm{pH} ;\left[\mathrm{H}^{+}\right]$, is the proton concentration; $K s_{1}$ is the lowest proton concentration where $r$ is equal to $1 / 2 r_{\max } ; K s_{2}$ is the highest proton concentration where $r$ is equal to $1 / 2 r_{\text {max }} ; p K s_{1}$, is the logarithm of the lowest $\mathrm{pH}$ at which $r$ is equal to $1 / 2 r_{\max } ; p K s_{2}$ is the logarithm of the highest $\mathrm{pH}$ at which $r$ is equal to $1 / 2 r_{\max }$.

If the pK values at which $r$ is equal to $1 / 2 r_{\max }$ are separated by more than $3.5 \mathrm{pH}$ units the model should fit $99 \%$ the data. On the contrary, if they are separated by less than 3.5 $\mathrm{pH}$ units, the maximum of the plot $r_{\text {max }} v s \mathrm{pH}$ will occur at a value significantly lower than the theoretical maximum and, consequently, the $\mathrm{pH}$ values at the half-maximum points will not correspond to the $\mathrm{pK}$ values (Segel, 1975) and, thus, the Michaelis $\mathrm{pH}$ function must be modified by an empiric factor (A) so that it reaches $r_{\max }$ as a central value (Glass et al. 1997). Therefore, equation (7) assumes the following form:

$$
\frac{r}{r_{\max }}=\frac{A}{1+10^{p K_{S 1}-p H}+10^{p H-p K_{S 2}}}
$$

The concentration vs time plots obtained from kinetic parameters reported in the literature were made integrating mass balances in batch reactor on software Matlab v 6.5. The $p K s_{1}$ and $p K s_{2}$ values were obtained by fitting of the $r / r_{\text {max }} v s$ pH plot by equation (8).

\section{Deviations determination}

The deviation between the experimental data and the values

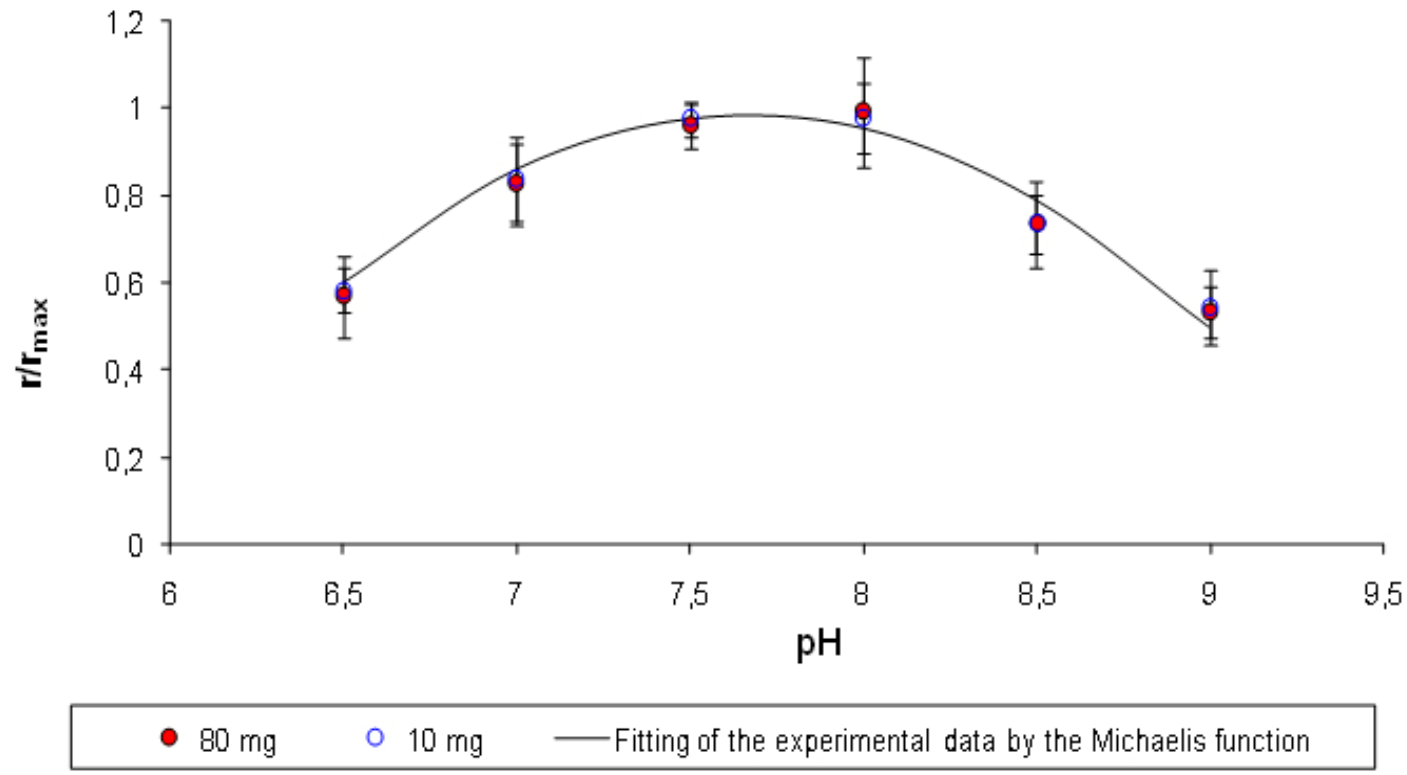

Figure 3. Effect of the $\mathrm{pH}$ on the $r / r_{\max }$ ratio (apparent maximum specific rate/maximum specific rate at the optimum $\mathrm{pH}$ ) of nitrite reduction $\left(\mathrm{C} / \mathrm{N}=10,37^{\circ} \mathrm{C}\right)$ at initial nitrate concentrations of $80 \mathrm{mg} \mathrm{NO}_{3}{ }^{-} \mathrm{N} \mathrm{L}^{-1}$ and $10 \mathrm{mg} \mathrm{NO}_{3}{ }^{-} \mathrm{N} \mathrm{L}^{-1}$. $(-3 / 4)$. Fitting of the experimental data by the Michaelis function $\left(R^{2}=0.97\right)$. 
given by the model using kinetic parameters reported in the literature, were calculated considering the experimental data as the true values.

$$
\frac{\sum_{i=1}^{n} \frac{X_{\text {Experimental }}-X_{\text {Model }}}{X_{\text {Experimental }}}}{n}
$$

\section{RESULTS AND DISCUSSION}

\section{Effect of the $\mathrm{pH}$ on the apparent maximum specific rate of nitrate reduction}

Assays at different $\mathrm{pH}$ values and different nitrate concentrations were carried out to determine the inhibitory effect of the $\mathrm{pH}$ on denitrification. Figure $1 \mathrm{a}$ and Figure $1 \mathrm{~b}$ shows the nitrate and nitrite concentration variation in assays performed at $\mathrm{pH} 8.0$ and an initial nitrate concentration of $10 \mathrm{mg} \mathrm{NO}{ }_{3}^{-}-\mathrm{N} \mathrm{L}^{-1}$ and $80 \mathrm{mg} \mathrm{NO}{ }_{3}^{-}-\mathrm{N} \mathrm{L}^{-1}$, respectively. As shown, nitrate concentration diminished with time while the nitrite concentration increased up to a peak at approximately $5 \mathrm{hrs}$ of starting the assay. A similar behaviour was observed at $\mathrm{pH}$ values of $6.5,7.0,8.0,8.5$ and 9.0. In these assays, TAN concentration varied between 64 and $142 \mathrm{mg} \mathrm{TAN} \mathrm{L}^{-1}$ and, according to the conditions under which were carried out the experiments $(\mathrm{pH}$ and temperature), the non-dissociated ammonia concentration was below $56.5 \mathrm{mg} \mathrm{NH}_{3}-\mathrm{N} \mathrm{L}^{-1}$ at $\mathrm{pH} 9.0$ and $0.12 \mathrm{mg} \mathrm{NH}_{3}$ $\mathrm{N} \mathrm{L}^{-1}$ at $\mathrm{pH}$ 6.5, i.e., far below the reported inhibitory concentrations for denitrification (Mosquera-Corral et al. 2001; Soto et al. 2007).

Figure 2 shows the $r / r_{\max }$ ratio as a function of the $\mathrm{pH}$ in assays performed at an initial $\mathrm{C} / \mathrm{N}$ of 10 and initial nitrate concentrations of 80 and $10 \mathrm{mg} \mathrm{NO} \mathrm{NO}_{3}^{-}-\mathrm{N} \mathrm{L}^{-1}$. Maximal nitrate consumption rates were obtained from the initial slope of the nitrate consumption vs. time plot at different $\mathrm{pH}$ values. As shown, the $r / r_{\max }$ ratio and, hence, the apparent maximum rate of nitrate consumption, reached a peak between $\mathrm{pH} \quad 7.5$ and 8.0 at initial nitrate concentrations of $10 \mathrm{mg} \mathrm{NO}_{3}^{-}-\mathrm{N} \mathrm{L}^{-1}$ and $80 \mathrm{mg} \mathrm{NO}_{3}^{-}-\mathrm{N} \mathrm{L}^{-1}$.

At an initial nitrate concentration of $80 \mathrm{mg} \mathrm{NO}_{3}{ }^{-}-\mathrm{N} \mathrm{L}^{-1}$, the apparent maximum rate diminished $50 \%$ when the $\mathrm{pH}$ was decreased from 8.0 to 7.0 and when increased from 8.0 to 9.0. At an initial nitrate concentration of $10 \mathrm{mg} \mathrm{NO}_{3}{ }^{-}-\mathrm{N} \mathrm{L}^{-1}$, the apparent maximum rate diminished $50 \%$ when the $\mathrm{pH}$ increased from 8.0 to 9.0, but when $\mathrm{pH}$ decreased from 8.0 to 7.0 , the apparent maximum rate diminished only $23 \%$. This behaviour might be ascribed to different $\mathrm{NO}_{2}^{-}-\mathrm{N}$ and $\mathrm{HNO}_{2}$ concentrations. According to Soto et al. (2007), a $10 \%$ reduction in the rate of nitrate reduction at $\mathrm{pH} 7.5$ is observed when the initial nitrate concentration is $74.24 \mathrm{mg}$ $\mathrm{NO}_{3}{ }^{-} \mathrm{L}^{-1}$, i.e., the actual minimum inhibitory concentration of nitrous acid would be $0.004 \mathrm{mg} \mathrm{HNO}_{2}-\mathrm{N} \mathrm{L}^{-1}$ (Soto et al. 2007). As shown in Table 1 , the maximal $\mathrm{HNO}_{2}$ concentrations that might be reached at an initial nitrate concentration of $10 \mathrm{mg} \mathrm{NO}{ }_{3}^{-}-\mathrm{N} \mathrm{L}^{-1}$ and, assuming that all the initial nitrate is reduced to nitrite and that nitrite is not further transform to gaseous nitrogen, are lower than 0.004 mg $\mathrm{HNO}_{2} \mathrm{~L}^{-1}$ within the $\mathrm{pH}$ range of 6.5-9.0, whereas at 80 mg $\mathrm{NO}_{3}^{-}-\mathrm{N} \mathrm{L}^{-1}$ the maximal $\mathrm{HNO}_{2}$ concentration is greater than $0.004 \mathrm{mg} \mathrm{HNO}_{2}-\mathrm{N} \mathrm{L}^{-1}$ when the $\mathrm{pH}$ diminished to 7.5. Thus, assays performed at an initial nitrate concentration of $80 \mathrm{mg} \mathrm{NO}{ }^{-}-\mathrm{N} \mathrm{L}^{-1}$ and at a pH lower than 7.5 would reflect the combined $\mathrm{HNO}_{2}$ inhibitory effect and the $\mathrm{pH}$ inhibitory effect on the denitrification rate while assays performed at $80 \mathrm{mg} \mathrm{NO}{ }_{3}^{-}-\mathrm{N} \mathrm{L}^{-1}$ at $\mathrm{pH}$ values higher than 7.5 would only reflect the inhibitory effect of the $\mathrm{pH}$ on the denitrification rate. On the other hand, assays performed at an initial nitrate concentration of $10 \mathrm{mg} \mathrm{NO}_{3}^{-}-\mathrm{N} \mathrm{L}^{-1}$ would reflect only the $\mathrm{pH}$ effect at the studied $\mathrm{pH}$ range.

The optimum rate was attained at $\mathrm{pH} 7.5$ to 8.0 , and no differences in rates were observed between both initial nitrate concentrations. This $\mathrm{pH}$ range is in agreement with those reported by Glass et al. (1997), who reported an optimum $\mathrm{pH}$ for denitrification close to 8.0 in an active sludge reactor with a nitrate and nitrite concentrations of $1350 \mathrm{mg} \mathrm{NO}_{3}^{-}-\mathrm{N} \mathrm{L}^{-1}$ and $15-2100 \mathrm{mg} \mathrm{NO}_{2}^{-}-\mathrm{N} \mathrm{L}^{-1}$, respectively. Almeida et al. (1995) reported an optimum $\mathrm{pH}$

Table 2. Experimental constants for the Monod equation for the nitrate reduction kinetics and for the Monod and Haldane equations for the nitrite reduction kinetics.

\begin{tabular}{|c|c|c|c|c|c|c|}
\hline Compound & Temperature ${ }^{\circ} \mathrm{C}$ & $\mathrm{pH}$ & $\stackrel{\mathrm{K}_{\mathrm{s}}}{\left[\mathrm{mg} \mathrm{L}^{-1}\right]}$ & $\frac{m_{\max } / y_{x / s}}{\left[m g(g \text { VSS h) })^{-1}\right]}$ & $\begin{array}{c}\mathrm{K}_{\mathrm{i}-\mathrm{NO} 2} \\
{\left[\mathrm{mg} \mathrm{L}^{-1}\right]}\end{array}$ & Reference \\
\hline Nitrate & 28 & 7.0 & 0.033 & 0.87 & - & \multirow{2}{*}{ Almeida et al. 1995} \\
\hline Nitrite & 28 & 7.0 & 0.074 & 0.40 & - & \\
\hline Nitrate & 37 & 7.5 & 0.47 & 1.27 & - & \multirow{2}{*}{ Soto et al. 2007} \\
\hline Nitrite & 37 & 7.5 & 0.36 & 1.38 & 906 & \\
\hline
\end{tabular}

${ }^{*}$ Results are expressed as the mean of 3 samples. 
of 7.0 for denitrification carried out by a pure culture of Pseudomonas fluorescens at $28^{\circ} \mathrm{C}$. This optimum is lower than the one found in this work; the difference might be due to the different bacterial strains used, as in this work a mixed bacterial culture was used to perform the experiments. In fact, Kunak et al. (2004) utilizing a pure culture of Paracoccus denitrificans, found optimal pHs at 6.2 for nitrite reductase and 7.5 for nitric oxide reductase at $30-40^{\circ} \mathrm{C}$; these values are also different from those reported by Almeida et al. (1995).

\section{Modelling of the effect of the $\mathrm{pH}$ on the rate of nitrate reduction}

The effect of the $\mathrm{pH}$ on the apparent maximum rate of nitrate reduction at an initial nitrate concentration of $10 \mathrm{mg}$ $\mathrm{NO}_{3}{ }^{-}-\mathrm{N} \mathrm{L}^{-1}$ was modelled by the Michaelis-type kinetics (equation 8). According to the Henderson-Hasselbach expression, the $\mathrm{HNO}_{2}$ concentration is negligible at the studied $\mathrm{pH}$ range; thus, at this nitrate concentration solely the $\mathrm{pH}$ affects the rate of denitrification. Figure 2 shows the fitting of the experimental data by the Michaelis model. The parameters $p K s_{1}$ and $p K s_{2}$ of the factor accounting for $\mathrm{pH}$ inhibition were calculated by fitting of the experimental data by equation (8). Fitting was carried out by the TableCurve 2D, program using the Levenberg-Marquardt method. The fitting of the experimental data gave the following parameter values: $p K s_{1}=6.27 \pm 0.204 ; p K s_{2}=$ $9.04 \pm 0.175$; maximum specific rate at the optimum $\mathrm{pH}=$ $1.32 \pm 0.24\left[\mathrm{mg} \mathrm{NO}_{3}{ }^{-}-\mathrm{N}\left(\mathrm{g} \mathrm{VSS} \mathrm{h}^{-1}\right]\right.$ and $\mathrm{A}=1.01 \pm 0.085$. As shown in Figure 2, the function gives a good prediction of the $r / r_{\max }$ ratio at $\mathrm{pH}<8.0$, as the predicted values lie within the experimental error range. At $\mathrm{pH}$ values over 8 (8.5 and 9), the function was not able to predict values within the experimental error range.

\section{Effect of the $\mathrm{pH}$ on the apparent maximum specific rate of nitrite reduction}

Figure 3 shows the apparent maximum specific rates of nitrite reduction at initial nitrate concentrations of $80 \mathrm{mg}$ $\mathrm{NO}_{3}{ }^{-}-\mathrm{N} \mathrm{L}^{-1}$ and $10 \mathrm{mg} \mathrm{NO}_{3}{ }^{-}-\mathrm{N} \mathrm{L}^{-1}$. Similarly as in nitrate reduction, the apparent maximum rate of nitrite consumption reached a peak between $\mathrm{pH}$ values of 7.5 and 8.0, at initial nitrate concentrations of $10 \mathrm{mg} \mathrm{NO}{ }_{3}^{-}-\mathrm{N} \mathrm{L}^{-1}$ and $80 \mathrm{mg} \mathrm{NO}{ }_{3}^{-}-\mathrm{N} \mathrm{L}^{-1}$. Hence, the optimum $\mathrm{pH}$ for nitrite reduction lies within these $\mathrm{pH}$ values. A decrease in $\mathrm{pH}$ from 8.0 to 6.5 or an increase in $\mathrm{pH}$ from 8.0 to 9.0 reduced by $40 \%$ the apparent nitrite consumption rate. This reduction can only be ascribed to a $\mathrm{pH}$ effect since a value of $0.05 \mathrm{mg} \mathrm{HNO}_{2}-\mathrm{N} \mathrm{L}^{-1}$ was calculated as the substrate concentration at maximum specific growth rate, $\mu_{\max }$ from the kinetic parameters reported by Soto et al. (2007). Therefore, as the $\mathrm{HNO}_{2}-\mathrm{N}$ concentration never surpassed this value at $\mathrm{pH}$ values of 6.5-9.0 (Table 1), only limitation by substrate but not substrate inhibition could have existed.

\section{Modelling of the effect of the $\mathrm{pH}$ on the apparent maximum specific rate of nitrite reduction}

The separate effect of the $\mathrm{pH}$ on the maximum rate of nitrite reduction at an initial nitrate concentration of $10 \mathrm{mg}$ $\mathrm{NO}_{3}{ }^{-}-\mathrm{N} \mathrm{L}^{-1}$ was modelled by the Michaelis function (equation 8). The parameters $p K s_{1}$ and $p K s_{2}$ of the factor accounting for $\mathrm{pH}$ inhibition were calculated by fitting of the experimental data by equation (8). Fitting was carried out by the TableCurve 2D, program using the LevenbergMarquardt method. Figure 3 shows the fitting of the experimental data by this function for an initial nitrate concentration of $10 \mathrm{mg} \mathrm{NO}{ }_{3}^{-}-\mathrm{N} \mathrm{L}^{-1}$; as shown, this function fitted the experimental data in the whole $\mathrm{pH}$ range studied.

Table 3. The deviation between the predicted values given by using the kinetic parameters reported by Soto et al. (2007) in the Monod and Haldane models and the experimental data obtained at different pH values.

\begin{tabular}{|c|c|c|c|c|}
\hline $\mathbf{p H}$ & Monod & Haldane & $\mathbf{p H}-$ Modified Monod & pH-Modified Haldane \\
\hline 6.5 & $\begin{array}{c}\text { Nitrate } \\
\text { reduction }\end{array}$ & $\begin{array}{c}\text { Nitrite } \\
\text { reduction }\end{array}$ & $\begin{array}{c}\text { Nitrate } \\
\text { reduction }\end{array}$ \\
\hline 7.0 & $42 \%$ & $75 \%$ & $12 \%$ & $10 \%$ \\
\hline 7.5 & $28 \%$ & $46 \%$ & $9 \%$ & $9 \%$ \\
\hline 8.0 & $13 \%$ & $15 \%$ & $13 \%$ & $15 \%$ \\
\hline 8.5 & $43 \%$ & $53 \%$ & $8 \%$ & $10 \%$ \\
\hline 9.0 & $33 \%$ & $43 \%$ & $10 \%$ & $12 \%$ \\
\hline Average error & $33.8 \%$ & $53.5 \%$ & $11 \%$ & $\mathbf{1 0 . 7}$ \\
\hline
\end{tabular}



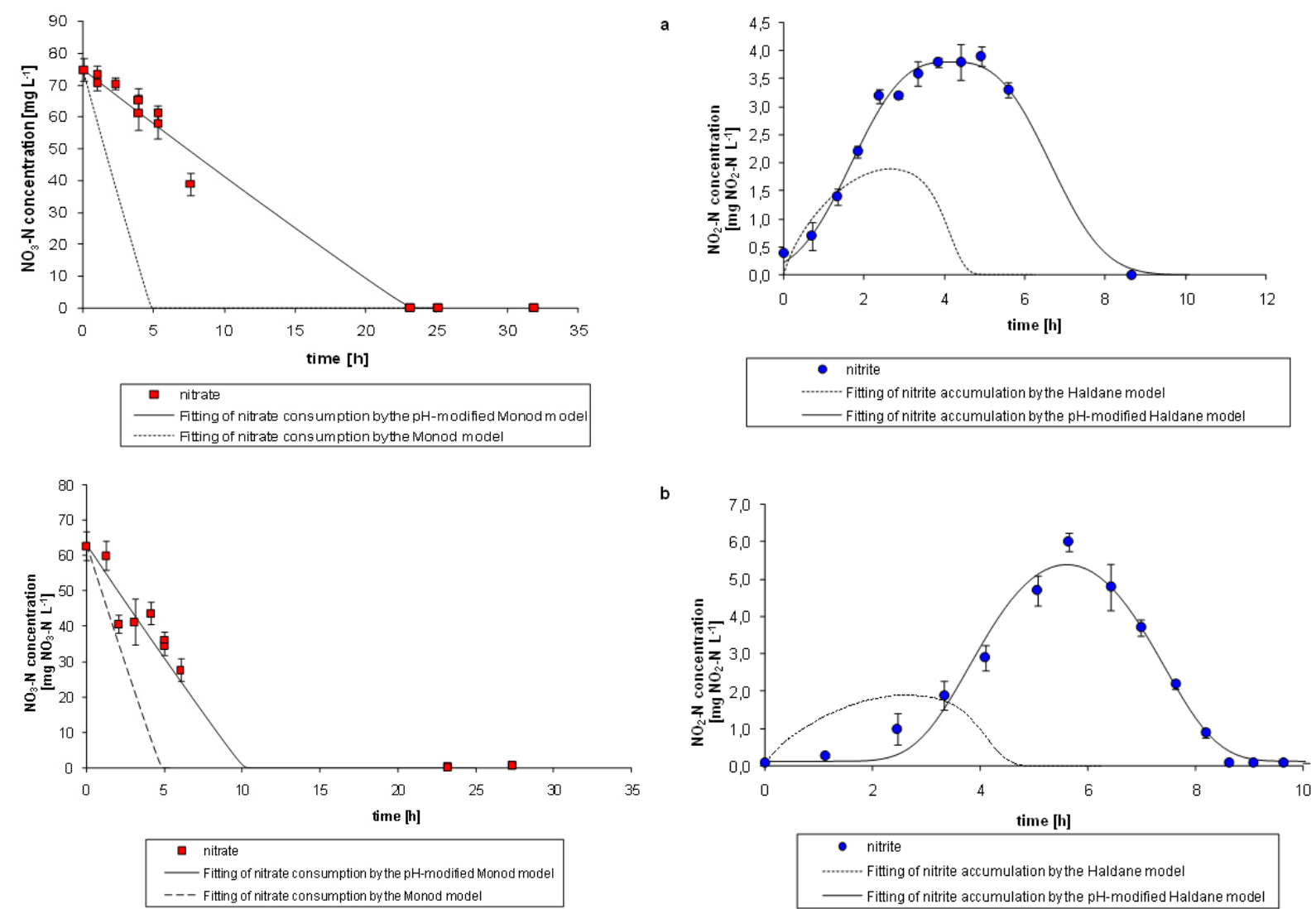

Figure 4. (a) Fitting by the Monod model and the pH-modified Monod model with kinetic parameters reported by Soto et al. (2007) of the experimental data for nitrate consumption at an initial nitrate concentration of $80 \mathrm{mg} \mathrm{NO}_{3}^{-}-\mathrm{N} \mathrm{L}^{-1}, \mathrm{pH}^{-1.5}$ and $37^{\circ} \mathrm{C}$. (-----) Fitting of nitrate consumption by the Monod model; (-3/4) Fitting of nitrate consumption by the pH-modified Monod model. (b) Fitting by the Monod model and the $\mathrm{pH}$-modified Monod model with kinetic parameters reported by Soto et al. (2007) of the experimental data for (ð) nitrate consumption at an initial nitrate concentration of $80 \mathrm{mg} \mathrm{NO}_{3}{ }^{-} \mathrm{N} \mathrm{L}^{-1}, \mathrm{pH} 9.0$ and $37^{\circ} \mathrm{C}$. (-----) Fitting of nitrate consumption by the Monod model; (3/4) Fitting of nitrate consumption by the $\mathrm{pH}$-modified Monod model. (c) Fitting by the Haldane model and the $\mathrm{pH}$ modified Haldane model with kinetic parameters reported by Soto et al. (2007) of the experimental data for (O) nitrite consumption at an initial nitrate concentration of $10 \mathrm{mg} \mathrm{NO}_{3}{ }^{-}-\mathrm{N} \mathrm{L}^{-1}, \mathrm{pH} 6.5$ and $37^{\circ} \mathrm{C}$. (----) Fitting of nitrite accumulation by the Haldane model; (-3/4) Fitting of nitrite accumulation by the $\mathrm{pH}$-modified Haldane model. (d) Fitting by the Haldane model and the $\mathrm{pH}$-modified Haldane model with kinetic parameters reported by Soto et al. (2007) of the experimental data for (O) nitrite consumption at an initial nitrate concentration of $10 \mathrm{mg} \mathrm{NO}_{3}^{-}-\mathrm{N} \mathrm{L}^{-1}, \mathrm{pH} 9.0$ and $37^{\circ} \mathrm{C}$. (----) Fitting of nitrite accumulation by the Haldane model; $(-3 / 4)$ Fitting of nitrite accumulation by the $\mathrm{pH}$-modified Haldane model.

The fitting of the experimental data gave the following parameter values: $p K s_{1}=6.41 \pm 0.072, p K s_{2}=8.93 \pm$ $0.065, \mathrm{r}_{\max }=1.07 \pm 0.08\left[\mathrm{mg} \mathrm{NO}_{2}^{-}-\mathrm{N}(\mathrm{g} \mathrm{VSS} \mathrm{h})^{-1}\right]$ and $\mathrm{A}=$ $1.09 \pm 0.024$.

\section{Quantification of the inhibitory effect of the $\mathrm{pH}$ in reported kinetic models}

Several authors have modelled the nitrate consumption rate by the Monod equation. However, the kinetic parameters they reported were obtained with different carbon sources, at a different temperature and/or different $\mathrm{pH}$ than the conditions used in this work (mainly protein as carbon source, $37^{\circ} \mathrm{C}$ and $\mathrm{pH}$ range $6.5-9.0$ ). Wild et al. (1995) reported kinetic parameters at $20^{\circ} \mathrm{C}$ with acetate as carbon source; moreover, Wild et al. (1995) performed their experiments at $\mathrm{pH}$ 7.0. On the other hand, Almeida et al.
(1995) reported kinetic parameters for denitrification obtained at $28^{\circ} \mathrm{C}, \mathrm{pH} 7.0$, with acetate as carbon source and using a pure culture of Pseudomonas fluorescens, while in this work denitrification was carried out by an anaerobic sludge adapted to nitrate. The kinetic parameters for the Monod model reported by Soto et al. (2007) were obtained at $\mathrm{pH}=7.5$ with the same inoculum and temperature used in this work although he used solely acetate as carbon source, thus, the experimental conditions used by Soto et al. (2007) were the closest to the ones used in this work. Therefore, the experimental nitrate and nitrite reduction kinetics at different pHs were compared to the Monod model with kinetic parameters reported by Soto et al. (2007). The constants for nitrate and nitrite reported by Almeida et al. (1995) and Soto et al. (2007) are shown in Table 2. 
The inclusion of the Michaelis function, which accounts for the effect of the $\mathrm{pH}$, in the Monod and in the Haldane model gives the following equations:

For nitrate reduction:

$$
\begin{aligned}
& r_{\mathrm{NO} 3}=r_{\text {max }, \mathrm{NO}_{3}^{-}} \frac{S_{\mathrm{NO} 3}}{K_{s_{\mathrm{NO} 3}}+S_{\mathrm{NO} 3}} \quad \frac{A}{1+10^{p K_{\mathrm{S}_{1}}^{-p H}}+10^{p H-p K} S_{2}} \\
& \text { (pH-modified Monod) }
\end{aligned}
$$

Similarly, for nitrite reduction:

$$
r_{\mathrm{NO} 2}=r_{\mathrm{max}, \mathrm{NO} 2} \frac{S_{\mathrm{NO} 2}}{K \mathrm{~S}_{\mathrm{NO} 2}+S_{\mathrm{NO2}}+\frac{S_{\mathrm{NO} 2}^{2}}{K_{l-\mathrm{NO} 2}}} \frac{\mathrm{A}}{1+10^{p K_{\mathrm{S}_{1}}{ }^{-p H}}+10^{p \mathrm{H}-p K_{S_{2}}}}
$$

(pH-modified Haldane)

Figure 4a and Figure 4b show the fittings by the Monod model and the $\mathrm{pH}$-modified Monod model with the kinetic parameters reported by Soto et al. (2007) of the experimental data for nitrate consumption at $\mathrm{pH} 6.5$ and 9.0, respectively, and at an initial nitrate concentration of $80 \mathrm{mg} \mathrm{NO}{ }_{3}^{-}-\mathrm{N} \mathrm{L}^{-1}$. Figure 4c and Figure $4 \mathrm{~d}$ show the fitting by the Haldane model and the $\mathrm{pH}$-modified Haldane model with the kinetic parameters reported by Soto et al. (2007) of the experimental data for nitrite accumulation at $\mathrm{pH} 6.5$ and 9.0, respectively, and at an initial nitrate concentration of $10 \mathrm{mg} \mathrm{NO} \mathrm{NO}_{3}^{-}-\mathrm{N} \mathrm{L}^{-1}$. As shown, the Monod and Haldane equations with the reported parameters gave a poor fitting of the experimental data for nitrate reduction and nitrite accumulation rates, respectively. Table 3 show the deviations between the experimental data for nitrate and nitrite consumption and the fitting by the Monod and Haldane kinetic models with the empiric constants reported by Soto et al. (2007) before and after including the Michaelis function. As an average, deviation diminished from $33.8 \%$ to $10.5 \%$ for nitrate reduction and from $53 \%$ to $10.7 \%$ for nitrite reduction upon inclusion of the factor representing the $\mathrm{pH}$ inhibition in their kinetic expressions. No differences were observed between the predicted values obtained with the original kinetic expression and those predicted by the modified kinetic expression at $\mathrm{pH} 7.5$, suggesting that the prediction of the nitrate and nitrite rates is not affected at this $\mathrm{pH}$ by the $\mathrm{pH}$ function. As shown, by introducing the Michaelis function, the fitting of the experimental data markedly improves, underlining the importance of including the $\mathrm{pH}$ effect on the denitrification kinetics.

Modelling by the $\mathrm{pH}$-modified Monod of the experimental data reported by Almeida et al. (1995) for nitrate and nitrite consumption at $\mathrm{pH} 7.0$ validated the use of the Michaelis function to quantify the effect of the $\mathrm{pH}$ in the denitrification kinetic. The Michaelis parameters calculated from the data reported by Almeida et al. (1995) were $\mathrm{pK}_{\mathrm{S} 1}$ $=6.3 ; \mathrm{pK}_{\mathrm{s} 2}=7.8$ and $\mathrm{A}=1.4$ for nitrate reduction and $\mathrm{pK}_{\mathrm{S} 1}$ $=6.4 ; \mathrm{pK}_{\mathrm{S} 2}=7.3$ and $\mathrm{A}=1.4$ for nitrite reduction. The errors between the fitting by the Monod model and the $\mathrm{pH}$ - modified Monod model of the experimental data reported by Almeida et al. (1995) at $\mathrm{pH}$ 6.6, 7.4 and 7.8 were $2.77 \%$, $4.15 \%$ and $2.74 \%$, respectively, for nitrate reduction and $5.21 \%, 10.18 \%$ and $9.55 \%$, respectively, for nitrite reduction. As shown, the errors are quite small except for the nitrite accumulation. The latter might be due to the fact that Almeida et al. (1995) used a very narrow $\mathrm{pH}$ range (6.6-7.8) and the calculated $p K s_{1}$ and $p K s_{2}$ values lie out of this $\mathrm{pH}$ range.

This function allows modelling of the kinetics of denitrification by one equation that integrates kinetic variables and the $\mathrm{pH}$ effect. These results shows that the effect of the $\mathrm{pH}$ should be taken into account in the modelling, operation and design of bacterial processes.

\section{CONCLUDING REMARKS}

The results of this work indicate that the inclusion of the $\mathrm{pH}$ effect through the Michaelis function in the kinetics of nitrate reduction and nitrite reduction clearly improves its predictive potential as it reduces the deviation between the predicted and experimental values from an average of $33.8 \%$ and $53.5 \%$ to $10.5 \%$ and $10.7 \%$ for nitrate reduction (Monod) and nitrite reduction (Haldane), respectively.

Thus, not only the pH-dependent $\mathrm{HNO}_{2}$ effect should be considered in the modelling of the kinetics of nitrate and nitrite reduction but also the $\mathrm{pH}$ effect should be taken into account in these processes.

\section{REFERENCES}

ALMEIDA, J.S.; JULIO, S.M.; REIS, M.A.M. and LARRONDO, M.J.T. Nitrite inhibition of denitrification by Pseudomonas fluorescens. Biotechnology and Bioengineering, May 1995, vol. 46, no. 3, p. 194-201.

ANGELIDAKI, I.; ELLEGAARD, L. and AHRING, B. A mathematical model for dynamic simulation of anaerobic digestion of complex substrates: focusing on ammonia inhibition. Biotechnology and Bioengineering, June 1993, vol. 42, no. 3, p. 159-166.

APHA, AWWA, WPCF, Standard Methods for the Examination of Water and Wastewater. $20^{\text {th }}$ ed. Amer. Public Health Assoc., Washington, D.C. 2002.

ASPÉ, E.; MARTÍ, M.C.; JARA, A. and ROECKEL, M. Ammonia inhibition in the anaerobic treatment of fishery effluents. Water Environment Research, April 2001, vol. 73, no. 2, p. 154-164.

BATSTONE, D.; KELLER, J.; ANGELIDAKI, I.; KALYUZHNYI, S.; PAVLOSTATHIS, S.; ROZZI, A.; SANDERS, W.; SIEGRIST, $H$. and VAVILIN, V. Anaerobic Digestion Model $N^{\circ} 1$ (ADM1). London, IWA Task Group for Mathematical Modelling of Anaerobic Digestion Processes, Scientific and Technical Report $\mathrm{N}^{\circ} 13$, 2002, 77 p. ISBN 1900222787. 
CAMPOS, E. and FLOTATS, X. Dynamic simulation of $\mathrm{pH}$ in anaerobic processes. Applied Biochemistry and Biotechnology, April-June 2003, vol. 109, no. 1-3, p. 63-76.

GLASS, C. and SILVERSTEIN, J. Denitrification kinetics of high nitrate concentration water: $\mathrm{pH}$ effect on inhibition and nitrite accumulation. Water Research, March 1998, vol. 32, no. 3, p. 831-839.

GLASS, C.; SILVERSTEIN, J. and OH, J. Inhibition of denitrification in activated sludge by nitrite. Water Environment Research, September-October 1997, vol. 69, no. 6, p. 1086-1093.

KUNAK, M.; KUCERA, I. and VAN SPANNING, R. Nitric oxide oscillations in Paracoccus denitrificans: the effects of environmental factors and of segregating nitrite reductase and nitric oxide reductase into separate cells. Archives of Biochemistry and Biophysics, September 2004, vol. 429, no. 2, p. 237-243.

MOSQUERA-CORRAL, A.; SANCHEZ, M.; CAMPOS, J.L.; MÉNDEZ, R. and LEMA, J.M. Simultaneous methanogenesis and denitrification of pretreated effluents from a fish canning industry. Water Research, February 2001, vol. 35, no. 2, p. 411-418.

RAMSAY, I.R. and PULLAMMANAPPALLIL, P.C. Fullscale application of a dynamic model for high-rate anaerobic wastewater treatment systems. Journal of Environmental Engineering-ASCE, July 2005, vol. 131, no. 7, p. 1030-1036.

RIVER, L.; ASPÉ, E.; ROECKEL, M. and MARTÍ, M.C. Evaluation of clean technology processes in the marine products processing industry.Journal of Chemical Technology and Biotechnology, November 1998, vol. 73, no. 3, p. 217-226.

SÁNCHEZ, O.; ASPÉ, E.; MARTI, M.C. and ROECKEL, M. Rate of ammonia oxidation in a synthetic saline wastewater by a nitrifying mixed-culture. Journal of Chemical Technology and Biotechnology, November 2005, vol. 80, no. 11, p. 1261-1267.

SEGEL, Irwin. Effects of $\mathrm{pH}$ and temperature. In: SEGEL, Irwined. Enzyme Kinetics. New York, USA, John Wiley \& Sons, Inc., 1975, p. 884-941.

SIEGRIST, H.; VOGT, D.; GARCIA-HERAS, J.L. and GUJER, W. Mathematical model for meso- and thermophilic anaerobic sewage sludge digestion. Environmental Science and Technology, March 2002, vol. 36, no. 5, p. 1113-1123.

SOTO, O.; ASPÉ, E. and ROECKEL, M. Kinetics of crossinhibited denitrification of a high load wastewater. Enzyme and Microbial Technology, May 2007, vol. 40, no. 6, p. 1627-1634.
WILD, D.; VON SCHULTHESS, R. and GUJER, W. Structured modelling of denitrification intermediates. Water Science and Technology, 1995, vol. 31, no. 2, p. 45-54. 